Article

\title{
A Typology of Spa-Goers in Southern Spain
}

\author{
Rosa Anaya-Aguilar (D), German Gemar *(i) and Carmen Anaya-Aguilar (i) \\ Department of Economics and Business Administration, Campus El Ejido, University of Malaga, s/n, \\ 29071 Malaga, Spain; ranaya@uma.es (R.A.-A.); canaya@uma.es (C.A.-A.) \\ * Correspondence: ggemar@uma.es
}

check for updates

Citation: Anaya-Aguilar, R.; Gemar, G.; Anaya-Aguilar, C. A Typology of Spa-Goers in Southern Spain. Sustainability 2021, 13, 3724. https:// doi.org/10.3390/su13073724

Academic Editor: Olimpia Meglio and Nadia Di Paola

Received: 16 February 2021

Accepted: 24 March 2021

Published: 26 March 2021

Publisher's Note: MDPI stays neutral with regard to jurisdictional claims in published maps and institutional affiliations.

Copyright: (c) 2021 by the authors. Licensee MDPI, Basel, Switzerland. This article is an open access article distributed under the terms and conditions of the Creative Commons Attribution (CC BY) license (https:// creativecommons.org/licenses/by/ $4.0 /)$.

\begin{abstract}
This study sought to obtain conglomerates of spa-goers in Andalusia, Spain, based on a survey of 10 spas' users. The data from 725 valid survey questionnaires were analysed using a quantitative approach. The results show that $44.6 \%$ of users are between 65 and 88 years old and more than $60 \%$ are women. Approximately $50 \%$ of the respondents are retired, and $60 \%$ report a monthly income of less than 1000 euros. Three clusters were identified in the segmentation analysis: users with lower, partial and higher satisfaction. Over half $(58 \%)$ of the respondents belong to the higher satisfaction segment. Thermal tourism evidently has a strong potential for attracting other tourist segments. Andalusia has thermal springs that attract many tourists, which are located in places of great natural beauty and are part of inland towns' economic development. The findings confirm the need to improve the existing understanding of spa-user typologies. The benefits derived from health tourism can be analyzed from the concept of value proposition for the company, the user, the community and its environment. To generate income, spa companies must meet the expectations of stakeholders and this begins with an organization that constantly learns and innovates to satisfy users. The managers of the spas lead these projects, introducing important changes in their offer, from traditional medical aspects to facilities and therapies based on relaxation and sustainable natural tourism, promoting their organizations with sustained objectives over time capable of satisfying all stakeholders, creating value capable of attracting and satisfying the different segments of spa tourists, as this study shows.
\end{abstract}

Keywords: spa; tourism; health; Andalusia; survey

\section{Introduction}

The human need to enjoy thermal spring water has existed since ancient times. Especially in Europe, thermal spring facilities have been fundamentally oriented towards health, while, in the United States, spa services have been more closely associated with a healthy lifestyle. Some tourism companies offer spa visits and other products related to quality of life and health $[1,2]$. The current growing interest in health is extremely wide-ranging, not only covering activities to counteract stress but also perceiving health services facilities as the perfect place to socialize. Thus, the term 'spa' needs to be understood in the broadest sense as incorporating relaxation, health, rehabilitation and socialization [2-4].

The present widespread interest in health and fitness has made natural spring spas with traditional medical treatments available in the background increasingly popular $[5,6]$. In particular, the demand for spa heat treatments is growing. Most natural spa tourists are older people, but spa managers are apparently unaware that the senior market segment has mixed needs.

Length of stay studies are crucial to a clearer understanding tourism's determinants $[7,8]$. Researchers' findings agree that age is the main determinant of length of stay in spas [9], as well as that these facilities' profitability largely depends on length of stay. Because age is so important, spa managers could benefit from studies focused on differentiating between various age segments to understand tourists' motivations more fully. 
The present research focused on users of spa services with traditional medical treatments to examine the reasons why tourists choose spa services and what differences appear among heterogeneous visitor groups. This study's main objective was to obtain conglomerates of spa-goers in Andalusia, Spain, based on a survey of 10 spas. Andalusia is a region in Southern Spain, with $87,268 \mathrm{~km}^{2}$ [10] and a population of over 8 million people [11], and recognized as one of the main destinations for sun and beach tourism (e.g., Costa del Sol, Marbella or Malaga) and for cultural tourism (e.g., Córdoba, Granada or Alhambra) [12] in which young foreign tourists stand out, active in summer and with a different profile in winter, with a majority of retirees [13-15]. However, until now, spas have not been extensively studied, and there is scope for scientific research [16].

The results help identify specific groups that can be reached with tailored marketing campaigns and contribute to theoretical and empirical research on spa tourism.

The remainder of this paper is structured as follows. Section 2 reviews the relevant literature. Section 3 covers the methodology, data collection procedures and questionnaire reliability. The results and discussion are presented in Section 4, with the conclusions appearing in Section 5.

\section{Literature Review}

Water has been perceived as a source of healing for millennia [9]. Thermal waters, in particular, have been used from ancient times to the present. Different cultures have exploited either natural structures or built facilities to improve access to mineral spring water. Thermal spas currently combine ancient techniques with more innovative approaches. In addition, health tourism's development has led to a new understanding of how to use hot springs, which requires greater specialization in spa services. These improvements mean that, every year, more people travel for spa-based health and wellness vacations. Internationally, wellness tourists spend an average of $\$ 1528$ per trip and 53\% more than the typical international tourist [17-19].

Spas, resorts, thermal spas and thalassotherapy centers use, among other approaches, hot thermal water, bathing techniques and respiratory applications. These techniques require the use of facilities such as showers, bathtubs, swimming pools, stoves or spray shower stalls. Thermal mud or other clay and herb wraps can also be found in these centers. All the innovations that have appeared over time have allowed spas to adapt to new types of clients' demands and needs [20,21]. Current trends include taking advantage of the chemical-physical components and natural biological complexity of thermal spa water's microbiota [22].

Traditionally, spas have been considered establishments in which therapies rely on natural sources of mineral water under professional supervision. Changes in most countries' legislation have allowed more spas to open even though they are not always geared towards serving only health purposes. In the last 20 years, mineral spring spas have thus introduced important innovations such as 'wellness treatments', which are therapies not necessarily related to health conditions. Alongside traditional medical treatments, other services are offered based on natural mineral water. As a result, spa services have become tourist attractions rather than just health products [23-25].

Spas strive to respond to heterogeneous clients' demands. Some clients seek healthcare, while others focus on wellness. These consumers fall into different groups even though they use similar services [2].

Tourism-related businesses are increasingly interested in the wellness tourism market as many countries have aging populations [26]. The tourism industry has learned that competitiveness cannot be based solely on price and competitive advantages have to be generated based on other aspects. A wide range of quality products and services can be decisive. Thermal springs establishments need to be attentive to these dynamics [27], including that a key variable strengthening tourist companies' continuity is length of stay [7-9]. Tourism company managers must thus design strategies to meet customers' needs and increase the profits associated with longer length of stay [9]. 
In the 21st century, spas reorient their activity towards health tourism, with new concepts and services, driven by people's desire for well-being, in accordance with the ideals linked to spas [20,23].

Spa users can thus have medical and wellness goals. These two groups have different motivations, as members of the first need treatment for medical conditions, but those of the second group are motivated to take care of their current health $[2,28]$.

In response to these demands, the spa industry has grown exponentially in recent decades. Spa facilities become important sources of income for hotels and resorts, although spa clients prefer good quality therapies at reasonable prices and with a high level of privacy [29,30].

Multiple changes in spa services have also resulted in a significantly altered customer profile. Thermal therapy users are mainly made up of older people [9], but spa users overall are now younger individuals with a higher income [23,24]. Researchers have additionally confirmed that these consumers fall into diverse age groups [31]. In addition, spa users' current level of education is noticeably higher, especially in large urban centres. Men and women, furthermore, now make up a similar proportion of these visitors [24]. However, various authors have reported that, although the perception that spas are mainly used by women is changing, managers must still deal with the reality that more women than men use these facilities [30].

Spa clients today travel various times a year, taking shorter trips and choosing 3or 4-star hotels [24]. These changes in customers' profile are forcing companies to get to know their guests better and try to retain their loyalty [24]. For example, Portugal's spa services and infrastructure have recently improved substantially, as have spa tourists' use of the Internet [24]. The present study focused in profiling spa-goers because they are changing more noticeably. The goal was to improve the existing knowledge about spa users and allow managers to redesign the services offered to increase consumer satisfaction and loyalty $[23,24,32]$.

Cluster analysis has often been used to create a typology of spa-goers. Chen et al.'s [26] study in Taiwan divided spa users into three groups: leisure and recreation, physical care and holistic categories. Another challenge previously addressed is to understand why some tourists choose spa destinations among the many tourism options available. In research conducted in Tokyo, tourists chose a spa destination whenever they were looking for a 'relaxing' experience [33]. In Serbia, a further study showed that clients could be classified according to different motivations: obsession with health and beauty, hedonism, rejuvenation, escape from routine, socialisation and relaxation [2].

To profile the clients who visit spas in Hong Kong, researchers also segmented these consumers according to their preferences [34]. Four segments were identified: pricesensitive, treatment-oriented, guarantee-sensitive and fewer days in advance booking spagoers. Scholars who studied spa visitors' lifestyle in Hong Kong identified the following segments: carefree, pleasure oriented, family focused, average and health conscious and intellectual consumers [25]. The cited study found that most Hong Kong spa-goers are health conscious and intellectual and they generally prefer day spas and enjoy body massage treatments. Other researchers in Poland investigated tourists' motivations to use traditional medical spas [35]. The cited authors identified three groups of reasons-tourism, prevention and treatment-as well as three tourist segments-treatment seekers, treatment and wellness seekers and treatment, wellness and tourism seekers.

Many researchers have concentrated on tourist satisfaction in specific mass tourism destinations, especially in high season, but few studies have examined visitors' satisfaction with off-season holiday destinations [15]. One exception is research carried out in Mallorca, a popular summer vacation destination and favourite off-season destination. Kozak and Rimmington [15] surveyed tourists who visited Mallorca in the low winter season. The cited researchers found that significant destination attributes include, among others, value for money, quality of accommodations, safety, cleanliness, sanitation and quality and variety of gastronomy. 
Destination managers must thus also keep visitors satisfied in order to retain their loyalty to the destination - even if the customers do not return themselves - and to get them to speak well of the destination as a way to attract new visitors. To this end, destination managers must improve infrastructure, especially giving priority to green areas. Experts agree that a solid base of loyal customers has great benefits for companies and tourism destinations. Cluster analysis is, therefore, an appropriate tool to segment tourism demand and meet tourist segments' needs $[20,36]$.

\section{Methodology}

\subsection{Data Collection Procedures}

We first estimated the target population, which is defined as the number of spa-users (i.e., number/year). This information was requested from the manager of each one of the Spas and was estimated at 53,231 users per year, with an age equal to or greater than 15 years old. The sample was stratified to coincide with 1 in every 10 spa-goer participants. The sample size was estimated using Equation (1):

$$
n_{c}=\operatorname{Deff} * n
$$

where $n_{c}$ is the size adjusted to ensure a complete sample (i.e., strata). Deff is the effect of the pattern of or relationship between the variance within stratified sampling and within simple random sampling. This effect was arbitrarily estimated a priori as 1.5, which is an overestimate. The decision to apply this value was made in order to estimate any proportion with an accuracy of 5\% and confidence level of $95 \%$, considering a priori the worst possibility $\left(p=q=0.5\right.$ ). This approach implied that $n=384$ and $n_{c}=576$, which was selected as the minimum.

The sample size and/or strata were the result of a proportional allocation (i.e., the largest spas visited more than one time during the survey). The final result was 725 valid surveys. This number coincides with the suggestion made by Martínez-González, Sánchez-Villegas and López del Burgo [37], namely, to include 10 subjects per analysed variable. This criterion established the sample size's adequacy since 500 subjects would be an extremely good sample size and 1000 or more subjects would be an excellent sample size.

\subsection{Reliability (Questionnaire Reliability)}

A cross-sectional survey design was applied, and the questionnaire had been previously validated in a study evaluating the quality of sun and beach tourism destinations on the Costa del Sol [38]. The final version of the present study's questionnaire contained only slight modifications. Once the adaptations were incorporated, a diagnostic test was performed to confirm test-retest reproducibility with 30 users who were 15-28 years old and who were not part of the main sample or from the 3 spas under study. The intraclass correlation coefficient or kappa index was used according to the type of variable (i.e., quantitative or qualitative) and valued based on the Landis-Koch scale [39].

\section{Results and Discussion}

As shown in Table 1, 44.6\% of spa users surveyed were between 65 and 88 years, and more than $60 \%$ were women. Approximately 50\% of the respondents were retired, and $37 \%$ were employed. In addition, $60 \%$ of the spa users reported that their monthly income was less than 1000 euros. A full $82 \%$ of those attending the selected establishments came from Andalusia. 
Table 1. Socio-demographic distribution of users $(n=725)$.

\begin{tabular}{|c|c|c|c|}
\hline \multirow{2}{*}{ Variable } & \multicolumn{2}{|c|}{ Sample } & \multirow{2}{*}{$\begin{array}{c}\text { Population } \\
\% \pm \mathrm{SE}^{1}\end{array}$} \\
\hline & Number & $(\%)$ & \\
\hline \multicolumn{4}{|l|}{ Age (years) } \\
\hline $15-35$ & 137 & -18.9 & $18.1 \pm 1.6$ \\
\hline $36-49$ & 116 & -16 & $14.6 \pm 1.5$ \\
\hline $50-64$ & 149 & -20.6 & $21.2 \pm 1.8$ \\
\hline $65-88$ & 323 & -44.6 & $46.1 \pm 2.1$ \\
\hline Mean $\pm \mathrm{SD} / \mathrm{SE}^{2}$ & \multicolumn{2}{|c|}{$55.2 \pm 18.3$} & $56.0 \pm 0.8$ \\
\hline \multicolumn{4}{|l|}{ Gender } \\
\hline Male & 286 & -39.4 & $38.2 \pm 2.1$ \\
\hline Female & 439 & -60.6 & $61.8 \pm 2.1$ \\
\hline \multicolumn{4}{|l|}{ Occupation } \\
\hline Employed & 268 & -37 & $34.0 \pm 2.0$ \\
\hline Housewife & 45 & -6.2 & $5.8 \pm 1.0$ \\
\hline Student $(n=48)$ or unemployed $(n=3)^{3}$ & 51 & -7 & $7.0 \pm 1.1$ \\
\hline Retired & 361 & -49.8 & $53.1 \pm 2.1$ \\
\hline \multicolumn{4}{|l|}{ Monthly income (euros) } \\
\hline$<500$ & 207 & -28.6 & $29.8 \pm 2.0$ \\
\hline $501-1000$ & 229 & -31.6 & $33.1 \pm 2.0$ \\
\hline $1001-1500$ & 194 & -26.8 & $26.6 \pm 1.9$ \\
\hline $1501-2000$ & 77 & -10.6 & $8.6 \pm 1.1$ \\
\hline $2001-2500$ & 11 & -1.5 & $1.0 \pm 0.3$ \\
\hline $2501-3000$ & 4 & -0.6 & $0.7 \pm 0.4$ \\
\hline$>3000$ & 3 & -0.4 & $0.2 \pm 0.1$ \\
\hline \multicolumn{4}{|l|}{ Region of origin 4} \\
\hline Total Andalusia & 596 & -82.2 & $82.9 \pm 1.6$ \\
\hline Canary Islands & 2 & -0.3 & $0.1 \pm 0.1$ \\
\hline Cantabria & 1 & -0.1 & $0.0 \pm 0.0$ \\
\hline Castilla León & 2 & -0.3 & $0.1 \pm 0.1$ \\
\hline Castilla Mancha & 13 & -1.8 & $2.6 \pm 0.8$ \\
\hline Catalonia & 22 & -3 & $2.3 \pm 0.5$ \\
\hline Estremadura & 3 & -0.4 & $0.2 \pm 0.1$ \\
\hline The Rioja & 2 & -0.3 & $0.2 \pm 0.1$ \\
\hline Madrid & 55 & -7.6 & $7.9 \pm 1.1$ \\
\hline Murcia & 4 & -0.6 & $1.1 \pm 0.6$ \\
\hline Basque Country & 2 & -0.3 & $0.2 \pm 0.2$ \\
\hline Valencia & 16 & -2.2 & $1.7 \pm 0.5$ \\
\hline Ceuta/Melilla & 7 & -1 & $0.5 \pm 0.2$ \\
\hline \multicolumn{4}{|l|}{ Andalusia provinces (over national total) } \\
\hline Almeria & 73 & -10.1 & $8.3 \pm 0.8$ \\
\hline Cadiz & 39 & -5.4 & $4.5 \pm 0.8$ \\
\hline Cordova & 25 & -3.4 & $2.7 \pm 0.6$ \\
\hline Pomegranate & 127 & -17.5 & $18.3 \pm 1.6$ \\
\hline Huelva & 5 & -0.7 & $0.9 \pm 0.5$ \\
\hline Jaen & 104 & -14.3 & $20.4 \pm 1.6$ \\
\hline Malaga & 178 & -24.6 & $21.9 \pm 1.7$ \\
\hline Seville & 45 & -6.2 & $5.7 \pm 1.0$ \\
\hline
\end{tabular}

${ }^{1} \mathrm{SE}=$ Population percentage \pm standard error (SE), taking into account the sample's weighting and stratified sampling (i.e., spas) and using SUDAAN software. ${ }^{2} \mathrm{SD}=$ standard deviation calculated for the sampling distribution; SE in the population distribution. ${ }^{3} n=$ number. ${ }^{4}$ No users in the sample were from abroad or from the regions of Aragon, Asturias, the Balearic Islands, Galicia or Navarra.

The data on spa-goers' age and gender ran parallel to other investigations of thermal springs tourism. Most attendees were women and over 60 years old [30,40]. However, Gonçalves and Guerra [31] found more diversity in age groups in their study of health 
tourism in Portugal. The current research's results coincide with other studies that found that spa users' region of origin was mainly Andalusia [9,40].

Significant differences were detected between the dimensions for the entire sample $(p<0.001)$. The segmentation technique (i.e., cluster analysis) applied identified three different clusters, which were labelled according to their members' average satisfaction value. The following groups were isolated: lower satisfaction, partial satisfaction and greater satisfaction. The latter had the most weight in the sample (see Table 2).

Table 2. Cluster analysis (conglomerates) $(n=725)^{1}$.

\begin{tabular}{|c|c|c|c|c|c|}
\hline \multirow{4}{*}{ Weight \% } & \multicolumn{3}{|c|}{ Clusters } & \multicolumn{2}{|c|}{ Comparison } \\
\hline & \multirow{2}{*}{$\begin{array}{c}\mathrm{A} \\
(n=131)^{2}\end{array}$} & \multirow{2}{*}{$\begin{array}{c}\text { B } \\
(n=245)\end{array}$} & \multirow{2}{*}{$\begin{array}{c}\text { C } \\
(n=349)\end{array}$} & \multirow{2}{*}{$p$-Global ${ }^{3}$} & \multirow{2}{*}{ In Pairs ${ }^{4}$} \\
\hline & & & & & \\
\hline & 16.8 & 25.2 & 58 & & \\
\hline \multicolumn{6}{|c|}{ Dimensions $(\text { mean } \pm \mathrm{SD})^{5}$} \\
\hline Accommodations & $4.65 \pm 0.93$ & $5.93 \pm 0.55$ & $6.23 \pm 0.66$ & $<0.001$ & $\mathrm{~A} \neq \mathrm{B} \neq \mathrm{C}$ \\
\hline Revitalisation & $4.04 \pm 0.97$ & $6.10 \pm 0.74$ & $6.37 \pm 0.70$ & $<0.001$ & $\mathrm{~A} \neq \mathrm{B} \neq \mathrm{C}$ \\
\hline Spa & $4.68 \pm 0.81$ & $6.00 \pm 0.58$ & $6.25 \pm 0.58$ & $<0.001$ & $\mathrm{~A} \neq \mathrm{B} \neq \mathrm{C}$ \\
\hline Sports & $2.24 \pm 1.03$ & $3.00 \pm 1.14$ & $4.68 \pm 1.56$ & $<0.001$ & $\mathrm{~A} \neq \mathrm{B} \neq \mathrm{C}$ \\
\hline Leisure & $3.29 \pm 1.11$ & $3.13 \pm 1.13$ & $5.29 \pm 0.91$ & $<0.001$ & $\mathrm{~A}, \mathrm{~B} \neq \mathrm{C}$ \\
\hline Public roads & $4.68 \pm 1.12$ & $5.98 \pm 0.84$ & $6.26 \pm 0.69$ & $<0.001$ & $\mathrm{~A} \neq \mathrm{B} \neq \mathrm{C}$ \\
\hline Infrastructure & $3.35 \pm 1.09$ & $3.10 \pm 1.02$ & $4.95 \pm 0.82$ & $<0.001$ & $\mathrm{~A}, \mathrm{~B} \neq \mathrm{C}$ \\
\hline Total & $4.07 \pm 0.55$ & $5.12 \pm 0.44$ & $5.88 \pm 0.48$ & $<0.001$ & $\mathrm{~A} \neq \mathrm{B} \neq \mathrm{C}$ \\
\hline
\end{tabular}

Interpretation approximation Lower satisfaction Partial satisfaction Higher satisfaction

${ }^{1}$ Based on the weighted sample, with the variables being the 7 scores in response to the main 52 -item questionnaire; the non-hierarchical method (i.e., k-means clustering) using SPSS for Windows 15.0 software and specifying three groups-after trying more options-by using the squared Euclidean distance as a measure of similarity. ${ }^{2} n=$ number. ${ }^{3}$ Calculated using SUDAAN software's REGRESS function and taking into account the sample's weighting and stratified sampling (i.e., spas). ${ }^{4}$ Estimated using SUDAAN software's DESCRIPT function and taking into account the sample's weighting and stratified sampling (i.e., spas); statistically different clusters indicated by the symbol $\neq$; $(p<0.05) .{ }^{5} \mathrm{SD}=$ Standard deviation.

The overall high level of satisfaction indicated a correlation with other researchers' findings that European tourists either feel good about or enjoy the amount of health treatment techniques offered [21]. The first cluster listed in Table 3 are users reporting the lowest satisfaction, who have the lowest average age ( 52.5 years old) and incomes between 501 and 1000 euros. These spa-goers mostly travel as a couple or family, choosing accommodations in 3- or 4-star hotels and staying an average of 8 nights. The group members who intend to return comprise $47.7 \%$ of the cluster.

Table 3. Description and comparison of clusters according to relevant variables $(n=725)^{1}$.

\begin{tabular}{|c|c|c|c|c|c|}
\hline \multirow{3}{*}{ Variable } & \multicolumn{3}{|c|}{ Clusters } & \multicolumn{2}{|c|}{ Comparison } \\
\hline & A & B & $\mathrm{C}$ & \multirow{2}{*}{$p$-Global ${ }^{3}$} & \multirow{2}{*}{ In Pairs } \\
\hline & $(n=131)^{2}$ & $(n=245)$ & $(n=349)$ & & \\
\hline Age $(\text { mean } \pm S D)^{5}$ & $52.5 \pm 19.2$ & $54.7 \pm 18.5$ & $57.5 \pm 17.6$ & 0.047 & $A \neq C$ \\
\hline Gender-female $(\% \pm \mathrm{EE})^{6}$ & $55.9 \pm 5.6$ & $62.1 \pm 3.5$ & $63.5 \pm 2.9$ & 0.483 & \\
\hline Occupation (retirees) $(\% \pm \mathrm{EE})$ & $44.3 \pm 5.5$ & $44.5 \pm 3.5$ & $59.4 \pm 2.9$ & 0.002 & \\
\hline \multicolumn{6}{|l|}{ Monthly income $(\% \pm \mathrm{EE})$} \\
\hline$<500$ euros & $25.7 \pm 4.8$ & $33.3 \pm 3.6$ & $29.4 \pm 2.7$ & \multirow{3}{*}{0.552} & \\
\hline 501-1000 euros & $38.9 \pm 5.5$ & $28.7 \pm 3.2$ & $33.4 \pm 2.8$ & & \\
\hline$>1000$ euros & $35.4 \pm 5.2$ & $38.0 \pm 3.4$ & $37.2 \pm 2.9$ & & \\
\hline Origin (Andalusia) $(\% \pm \mathrm{EE})$ & $73.0 \pm 4.9$ & $85.3 \pm 2.5$ & $84.7 \pm 2.1$ & 0.07 & \\
\hline
\end{tabular}


Table 3. Cont.

\begin{tabular}{|c|c|c|c|c|c|}
\hline \multirow{3}{*}{ Variable } & \multicolumn{3}{|c|}{ Clusters } & \multicolumn{2}{|c|}{ Comparison } \\
\hline & \multirow{2}{*}{$\begin{array}{c}\mathrm{A} \\
(n=131)^{2}\end{array}$} & \multirow{2}{*}{$\begin{array}{c}\text { B } \\
(n=245)\end{array}$} & \multirow{2}{*}{$\begin{array}{c}\mathrm{C} \\
(n=349)\end{array}$} & \multirow{2}{*}{$p$-Global ${ }^{3}$} & \multirow{2}{*}{ In Pairs 4} \\
\hline & & & & & \\
\hline \multicolumn{6}{|l|}{ Travel group (\% $\pm \mathrm{EE})$} \\
\hline Solo & $6.0 \pm 2.2$ & $17.5 \pm 3.0$ & $12.9 \pm 2.0$ & \multirow{4}{*}{0.021} & \multirow{4}{*}{$\mathrm{A} \neq \mathrm{B}, \mathrm{C}$} \\
\hline Couple & $49.5 \pm 5.6$ & $48.3 \pm 3.6$ & $53.1 \pm 3.0$ & & \\
\hline Friends & $12.7 \pm 3.8$ & $16.2 \pm 3.0$ & $16.8 \pm 2.3$ & & \\
\hline Family/Others & $31.9 \pm 5.1$ & $18.0 \pm 2.6$ & $17.3 \pm 2.3$ & & \\
\hline \multicolumn{6}{|l|}{ Accommodation type $(\% \pm \mathrm{EE})$} \\
\hline No/rented family house/apart-hotel & $22.8 \pm 3.8$ & $25.1 \pm 2.8$ & $10.2 \pm 1.6$ & \multirow{4}{*}{$<0.001$} & \multirow{4}{*}{$\mathrm{A} \neq \mathrm{B} \neq \mathrm{C}$} \\
\hline 2-star hostel/hotel & $23.5 \pm 4.9$ & $34.7 \pm 3.2$ & $17.5 \pm 2.2$ & & \\
\hline 3-/4-star hotel & $43.8 \pm 5.6$ & $16.1 \pm 3.0$ & $66.6 \pm 2.5$ & & \\
\hline Spa & $9.8 \pm 2.6$ & $24.0 \pm 2.4$ & $5.7 \pm 1.2$ & & \\
\hline Overnight stays (mean \pm of) & $7.7 \pm 5.1$ & $6.9 \pm 5.3$ & $8.5 \pm 4.7$ & 0.002 & $B \neq C$ \\
\hline Volume in pipeline this year or next $(\% \pm \mathrm{EE})$ & $47.7 \pm 5.6$ & $80.9 \pm 3.0$ & $79.8 \pm 2.5$ & $<0.001$ & \\
\hline \multicolumn{6}{|c|}{$\begin{array}{l}{ }^{1} \text { Based on the weighted sample and clusters formed from the } 7 \text { satisfaction scores used to respond to the main 52-item questionnaire } \\
\text { (see Section } 3) .{ }^{2} n=\text { number. }{ }^{3} \text { Calculated using the REGRESS function of SUDAAN (quantitative variables) or CROSSTAB (qualitative } \\
\text { variables) software and taking into account the sample's weighting and stratified sampling (i.e., spas). }{ }^{4} \text { Estimated using the DESCRIPT } \\
\text { function of SUDAAN (quantitative variables) or CROSSTAB (qualitative variables) software and taking into account the sample's weighting } \\
\text { and stratified sampling (i.e. spas); statistically different clusters indicated by the symbol } \neq(p<0.05) .{ }^{5} \text { SD = standard deviation. } \\
{ }^{6} \mathrm{EE}=\text { effect estimate; standard error corrected by stratified sampling. }\end{array}$} \\
\hline
\end{tabular}

The second cluster contains those users reporting only partial satisfaction, who are on average 54.7 years old and predominantly women and retirees. This group includes spagoers with low incomes (33.3\%) and others with high incomes (38.0\%). The majority come from Andalusia, travel as a couple or family and stay overnight in 2-star hotels (34.7\%).

The third cluster comprises the most satisfied users, who have a higher average age (57.5 years old). Most are women (63.5\%), with both average incomes $(33.4 \%)$ and higher incomes (37.2\%). Most users travel as a couple and stay in 3- or 4-star hotels (53.1 and $66.6 \%$, respectively). These spa-goers stay overnight more days (8.5) and mostly intend to return $(79.8 \%)$.

The third cluster of those with greater satisfaction coincides with other authors' conclusions regarding the association of spas with disease and older people [9]. These users' older average age could be related to Spain's Instituto de Mayores y Servicios Sociales (Institute for the Elderly and Social Services) programme. In addition, complementary spa services are promoted by the Spanish Ministry of Health, Social Services and Equality and offered to people over the age of 60 .

As mentioned previously, health tourism may also be spreading among young people with less free time and financial resources or individuals more affected by recent economic crises [41,42]. The increased demand from younger market segments can be deduced from the results of prior research in countries such as Portugal or Poland [31,35]. Other emerging trends or marketing strategies can further be inferred from spa centres' good Internet position and spa tourism's high potential [43].

If the segments extracted in this study are compared with the profile of the sun and beach tourist segment in which Andalusia stands out internationally, significant differences are found since the sun and beach tourist is younger, is active in the labour market and is foreigner [13,14].

The third cluster resembles the tourism received in the sun and beach destination in winter [15].

While the origin of tourists visiting the spas come mainly from Spain and nearby areas, this affects average spending. In the spas in other European countries, the national spa tourist spends more on average than the Andalusian spa tourists [17,19].

A differentiating characteristic between the three segments found lies in the main motivation to visit the destination, highlighting above all the medical and health aspects in 
the upper average age segment compared to the motivation of relaxation and well-being in the younger segment. This finding contrasts with the international trends found in the literature review where spa managers are aware of these two trends, health and wellness, reorienting their services to meet the expectations of both demands and the result of which is exponential growth $[2,20,23,29]$.

\section{Conclusions}

Thermal waters have been used since ancient times, and, currently, thousands of people travel every year to thermal spring centres looking for healthy vacations and improved health and wellbeing. Thermal springs tourism has been shown to have a strong potential for growth that could include attracting other tourist segments. Spain's Andalusia region, in particular, has thermal spring facilities that attract many tourists, that are located in locations of great natural beauty and that are part of inland towns' economic development.

The present results are important to academics as these findings can strengthen the existing understanding of spa tourists' socio-demographic profile and behaviour. Concurrently, the results are interesting in that they reveal how spa resort tourists evaluate infrastructure and services. The findings could also be quite useful to local governments and all companies dedicated to this tourism niche, including not only the firms that develop products but also those that market them.

The findings of this research could have important implications for tourism entrepreneurs, offering new strategies that contribute to diversification and provide spa hotels with solutions that attract guests interested in improving their health and well being.

In view of the results obtained, conclusions are drawn for management, such as, for example, that companies could develop strategies to attract users with different profiles, with activities, prices, or spaces that are more appropriate to their needs and looking for the conditions to increase attracting other segments and of course promoting the loyalty of those who are already identified.

This research presents the limitation that the information could have been obtained at the population level to later adjust the sample distribution, which presented a great complexity that was discarded from the beginning to facilitate the collaboration of the participating spas. The collaboration of the Spas was limited to providing us with the population size per Spa or the number of clients served, but not the rest of the characteristics. Therefore we had to obtain this information from the sample. The size of each Spa is what allowed, in the SUDAAN statistical program, to weight the sample according to said size in order to make statistical inference. Its high response rate thus avoided selection bias.

This study's main limitation was analyses limited to the Andalusia region, but in the opinion of the authors they do not compromise the results since they can be extrapolated to any Spa in Spain or any country with similar climatic conditions. Additional lines of research could thus be carried out in the future to complement the data presented here.

Author Contributions: Conceptualization, R.A.-A.; methodology, R.A.-A., G.G. and C.A.-A.; software, R.A.-A., G.G. and C.A.-A.; validation, R.A.-A., G.G. and C.A.-A.; formal analysis, R.A.-A., G.G. and C.A.-A.; investigation, R.A.-A., G.G. and C.A.-A.; resources, R.A.-A., G.G. and C.A.-A.; data curation, R.A.-A., G.G. and C.A.-A.; writing-original draft preparation, R.A.-A., G.G. and C.A.-A.; writing-review and editing, R.A.-A., G.G. and C.A.-A.; visualization, R.A.-A., G.G. and C.A.-A.; supervision, R.A.-A., G.G. and C.A.-A.; project administration, R.A.-A., G.G. and C.A.-A. All authors have read and agreed to the published version of the manuscript.

Funding: This research received no external funding.

Institutional Review Board Statement: Not applicable.

Informed Consent Statement: Not applicable.

Data Availability Statement: The data presented in this study are available on request from the corresponding author. 
Acknowledgments: The authors would like to thank the professionals and experts of the Andalusian spa sector for their participation in this research project.

Conflicts of Interest: The authors declare no conflict of interest.

\section{References}

1. Chen, J.S.; Prebensen, N.; Huan, T.C. Determining the motivation of wellness travelers. Anatolia 2008, 19, 103-115. [CrossRef]

2. Dimitrovski, D.; Todorović, A. Clustering wellness tourists in spa environment. Tour. Manag. Perspect. 2015, 16, 259-265. [CrossRef]

3. Koh, S.; Yoo, J.J.E.; Boger, C.A. Importance-performance analysis with benefit segmentation of spa goers. Int. J. Contemp. Hosp. Manag. 2010, 22, 718-735. [CrossRef]

4. Loureiro, S.M.C.; Almeida, M.; Rita, P. The effect of atmospheric cues and involvement on pleasure and relaxation: The spa hotel context. Int. J. Hosp. Manag. 2013, 35, 35-43. [CrossRef]

5. Mak, A.H.N.; Wong, K.K.F.; Chang, R.C.Y. Health or self-indulgence? The motivations and characteristics of spa-goers. Proc. Int. J. Tour. Res. 2009, 11, 185-199. [CrossRef]

6. Anaya-Aguilar, R.; Gemar, G.; Anaya-Aguilar, C. Usability Analysis of Andalusian Spas' Websites. Sustainability 2021, 13, 2307. [CrossRef]

7. Soler, I.P.; Gemar, G.; Correia, M.B. Length of stay for tourists' inland trips. J. Destin. Mark. Manag. 2018, 10, 49-60. [CrossRef]

8. Soler, I.P.; Gemar, G.; Correia, M.B. The climate index-length of stay nexus. J. Sustain. Tour. 2020, 28, 1272-1289. [CrossRef]

9. Esiyok, B.; Kurtulmuşoğlu, F.B.; Özdemir, A. Heterogeneity in the determinants of length of stay across middle age and senior age groups in thermal tourism. J. Travel Tour. Mark. 2018, 35, 531-540. [CrossRef]

10. Junta de Andalucia Geographical Location-Official Andalusia Tourism Website. Available online: https://www.andalucia.org/ en/discover-us/geographical-location (accessed on 3 March 2021).

11. IECA Instituto Estadistica y Cartografia de Andalucia. Junta de Andalucía Padrón Municipal de Habitantes. Cifras Oficiales de Población Municipal I Instituto de Estadística y Cartografía de Andalucía. Available online: https://www.juntadeandalucia.es/ institutodeestadisticaycartografia/padron/index.htm (accessed on 3 March 2021).

12. IECA Instituto Estadistica y Cartografia de Andalucia-Junta de Andalucia Encuesta de Coyuntura Turística de Andalucía. Cuarto Trimestre 2019 y año 2020 | Instituto de Estadística y Cartografía de Andalucía. Available online: https://www. juntadeandalucia.es/institutodeestadisticaycartografia/turismo/notaprensa.htm (accessed on 3 March 2021).

13. Consejería de Turismo y Comercio de Andalucía Turismo de Salud y Bienestar. Available online: https://www.juntadeandalucia. es/turismoydeporte/opencms/areas/servicios/centro-documentacion/publicaciones/turismo/Turismo-de-salud-y-bienestaren-Andalucia-00001/ (accessed on 3 March 2021).

14. Otero Cordones, C. Evaluación de la Calidad de Destinos Turísticos de sol y Playa: Una Aplicación a la Costa del Sol, Universidad de Málaga, 2003. Available online: http:/ / www.biblioteca.uma.es/bbldoc/tesisuma/16699336.pdf (accessed on 24 January 2021).

15. Kozak, M.; Rimmington, M. Tourist Satisfaction with Mallorca, Spain, as an Off-Season Holiday Destination. J. Travel Res. 2000, 38, 260-269. [CrossRef]

16. Cong, L.C. A formative model of the relationship between destination quality, tourist satisfaction and intentional loyalty: An empirical test in Vietnam. J. Hosp. Tour. Manag. 2016, 26, 50-62. [CrossRef]

17. Global Wellness Institute. Available online: https://globalwellnessinstitute.org/ (accessed on 24 January 2021).

18. Szromek, A.R.; Wybrańczyk, K. Proposal of Value for Customer of Spas: Expectations of Spa Patients and Tourist in Polish Spas. Sustainability 2019, 11, 3598. [CrossRef]

19. Szromek, A.R.; Naramski, M. A Business Model in Spa Tourism Enterprises: Case Study from Poland. Sustainability 2019, 11, 2880. [CrossRef]

20. de la Hoz-Correa, A.; Muñoz-Leiva, F.; Bakucz, M. Past themes and future trends in medical tourism research: A co-word analysis. Tour. Manag. 2018, 65, 200-211. [CrossRef]

21. Gómez Pérez, C.P.; González Soutelo, S.; Mourelle Mosqueira, M.L.; Legido Soto, J.L. Spa techniques and technologies: From the past to the present. Sustain. Water Resour. Manag. 2019, 5, 71-81. [CrossRef]

22. Valeriani, F.; Margarucci, L.M.; Spica, V.R. Recreational use of spa thermal waters: Criticisms and perspectives for innovative treatments. Int. J. Environ. Res. Public Health 2018, 15, 2675. [CrossRef] [PubMed]

23. Gustavo, N.S. A 21st-century approach to health tourism spas: The case of Portugal. J. Hosp. Tour. Manag. 2010, 17, 127-135. [CrossRef]

24. Joukes, V.; Gerry, C. Website effectiveness in wellness promotion by Portuguese spas. J. Hosp. Tour. Manag. 2010, 17, 136-143. [CrossRef]

25. Kucukusta, D.; Denizci Guillet, B. Lifestyle Segmentation of Spa Users: A Study of Inbound Travelers to Hong Kong. Asia Pacific J. Tour. Res. 2016, 21, 239-258. [CrossRef]

26. Chen, K.H.; Liu, H.H.; Chang, F.H. Essential customer service factors and the segmentation of older visitors within wellness tourism based on hot springs hotels. Int. J. Hosp. Manag. 2013, 35, 122-132. [CrossRef]

27. Alén, E.; De Carlos, P.; Domínguez, T. An analysis of differentiation strategies for Galician thermal centres. Curr. Issues Tour. 2014, 17, 499-517. [CrossRef] 
28. Anaya-Aguilar, R.; Gemar, G.; Anaya-Aguilar, C. Challenges of Spa Tourism in Andalusia: Experts' Proposed Solutions. Int. J. Environ. Res. Public Health 2021, 18, 1829. [CrossRef] [PubMed]

29. Kucukusta, D.; Denizci Guillet, B. Measuring spa-goers' preferences: A conjoint analysis approach. Int. J. Hosp. Manag. 2014, 41, 115-124. [CrossRef]

30. Anaya-Aguilar, R.; Anaya-Aguilar, C.; Bravo-Pérez, M. Balneario: La definición de una tradición milenaria en Andalucía. Rev. Derecho Empres. Soc. 2017, 11, 237-246.

31. Gonçalves, E.C.; Guerra, R.J.d.C. O turismo de saúde e bem-estar como fator de desenvolvimento local: Uma análise à oferta termal portuguesa. PASOS. Rev. Tur. Patrim. Cult. 2019, 17, 453-472. [CrossRef]

32. Anaya-Aguilar, R.; Gemar, G.; Anaya-Aguilar, C. Factors Associated with Spa Tourists' Satisfaction. Mathematics 2021, 9 , 332. [CrossRef]

33. Kamata, H.; Misui, Y. Why do they choose a spa destination? The case of Japanese tourists. Tour. Econ. 2015, 21, 283-305. [CrossRef]

34. Guo, Y.; Denizci Guillet, B.; Kucukusta, D.; Law, R. Segmenting Spa Customers Based on Rate Fences Using Conjoint and Cluster Analyses. Asia Pacific J. Tour. Res. 2016, 21, 118-136. [CrossRef]

35. Dryglas, D.; Salamaga, M. Segmentation by push motives in health tourism destinations: A case study of Polish spa resorts. J. Destin. Mark. Manag. 2018, 9, 234-246. [CrossRef]

36. Castro, C.B.; Armario, E.M.; Ruiz, D.M. The influence of market heterogeneity on the relationship between a destination's image and tourists ' future behaviour. Tour. Manag. 2007, 28, 175-187. [CrossRef]

37. Martínez-González, M.A.; Sánchez-Villegas, A.; López del Burgo, C. Introducción a los modelos multivariables. In Bioestadística Amigable; Martínez-González, M.A., Sánchez-Villegas, A., Faulín-Fajardo, F.J., Eds.; Ediciones Díaz de Santos: Madrid, Spain, 2006; pp. 685-750. ISBN 84-7978-791-0.

38. Otero Moreno, J.; Otero Cordones, C. Evaluación de la calidad de destinos turísticos: El caso de la Costa del Sol. Pap. Econ. Española 2004, 102, 236-249.

39. Landis, J.R.; Koch, G.G. The Measurement of Observer Agreement for Categorical Data. Biometrics 1977, 33, 159. [CrossRef] [PubMed]

40. Alvim Carvalho, F. Estudo de Caso Sobre o Tipo de Uso, Exploraçâo e Gestâo das Águas Termais de Alhama de Granada (Andalucía): Uma Análise Partindo da Perspectiva do Desenvolvimento Sustentável. Ph.D. Thesis, Universidad Pablo de Olavide, Sevilla, Spain, 2016. Available online: http:/ / hdl.handle.net/10433/2732 (accessed on 1 March 2021).

41. Molinillo, S.; Japutra, A. Factors influencing domestic tourist attendance at cultural attractions in Andalusia, Spain. J. Destin. Mark. Manag. 2017. [CrossRef]

42. Papatheodorou, A.; Rosselló, J.; Xiao, H. Global Economic Crisis and Tourism: Consequences and Perspectives. J. Travel Res. 2010, 49,39-45. [CrossRef]

43. Padilla Meléndez, A.; Del Águila Obra, A.R.; Garrido Moreno, A.; Jiménez Espejo, R. Turismo de belleza y salud en la provincia de Málaga. Cámara Málaga 2010. [CrossRef] 